\title{
A Practical Example of Risk Assessment - Risk Assessment to Phycotoxins in a Recreational Shellfish Harvester's Subpopulation
}

\author{
Cyndie Picot and Alain-Claude Roudot \\ Laboratoire de Toxicologie Alimentaire et Cellulaire (EA 3880), \\ Université Européenne de Bretagne, Université de Bretagne Occidentale (UEB-UBO)
}

France

\section{Introduction}

The past few decades have seen an increase in the frequency, concentrations, and geographic distribution of marine algal toxins (phycotoxins), secondary metabolites produced by marine microalgae (phytoplankton). Among the 3400-4000 known phytoplankton species, only about $2 \%$ are potentially harmful (Frémy \& Lassus, 2001). Bivalve molluscs filter-feed on these micro-algae, accumulate toxins, and may be consumed by humans (Shumway et al,. 1995; Van Dolah, 2000). In order to determine whether phycotoxins are a matter of concern for human health, a risk assessment must be undertaken. It comprises four steps: hazard identification, hazard characterization, exposure assessment and risk characterization (WHO, 1985).

\section{Risk assessment}

Hazard identification is defined as follows: "the identification of biological, chemical and physical agents capable of causing adverse health effects and that may be present in a particular food or group of foods" (CAC, 2006). The outcome is a scientific judgment as to know whether the chemical being evaluated could, under given exposure conditions, cause an adverse effect in humans. In view of reported intoxications and deaths, phycotoxins are identified as a matter of concern for human health. Because of their high and increasing occurrence, their worldwide distribution and their different profile of toxicology and contamination, this chapter focused on two families of phycotoxins: okadaic acid (OA) and analogs, and spirolide (SPX) and analogs (Ade et al., 2003; Hallegraeff, 2003; EFSA, 2008a ; EFSA, 2010).

Hazard characterization (also known as dose-response assessment) is defined as: "the qualitative and/or quantitative evaluation of the nature of the adverse health effects associated with biological, chemical, and physical agents that may be present in food" (CAC, 2006). It describes the relationship between the ingested quantity of the substance and the incidence of an adverse health effect (CAC, 2006). The aim is to allocate two 
toxicological reference values: the Acute Reference Dose (ARfD) and the Tolerable Daily Intake (TDI) for acute and chronic risks, respectively. The ARfD and the TDI are the amount of a substance, in $\mathrm{mg} / \mathrm{kg}$ bw, which can be ingested without adverse health effects, for one meal or on a daily basis during a life time, respectively. Concerning acute hazard characterization, based on human and animal data, provisional ARfD have been allocated to OA, but a lack of data does not allow to allocate an ARfD to SPX. Moreover, concerning chronic hazards, the lack of (sub)chronic data for animals prevented international expert committees from allocating TDI to these toxins (Toyofuku, 2006; EFSA, 2008a; EFSA, 2010).

Exposure assessment is the evaluation of the likely intake of chemicals via food. It combines the level of the chemical in the diet and the consumption rates of the foods containing the chemical (Kroes et al., 2002; EFSA, 2008b). Exposure assessment must firstly concern at risk subpopulation. Recreational shellfish harvesters appear to be an at risk subpopulation because a priori they consumed a larger quantity of seafood than the general population, because their practice is both recreational and a free source of food (Burger et al., 1998, Gagnon et al., 2004; Leblanc, 2006). Unfortunately the shellfish harvester subpopulation is generally not taken into account (USEPA, 1998) and no exposure assessment to phycotoxins by recreative shellfish harvesters is available. Indeed, achieving a meaningful exposure assessment on phycotoxins by recreational shellfish harvesters is extremely difficult because of: i) the consumption data often do not distinguish between fish and shellfish, between purchased shellfish and recreationally harvested shellfish between the general population and specific subpopulations, and between shellfish species; ii) the contamination data reveal great variations between shellfish species, toxin profiles, inter- and intra-country levels; iii) consumption and contamination data are derived from different and unrelated studies.

Therefore it is critical to assess the phycotoxin dietary intakes from shellfish consumption in this at risk subpopulation. These considerations led us to monthly monitor these phycotoxins in harvested shellfish and to conduct a one-year survey of shellfish consumption by recreational shellfish harvesters. Then these data were combined with a probabilistic method to assess the exposure.

In the risk characterization phase, acute and chronic exposure intakes are compared with ARfD and TDI, respectively, to assess whether or not the presence of contaminant is a matter of concern (WHO, 1985).

\section{Practical example: Risk assessment to phycotoxins in a recreational shellfish harvester's subpopulation}

\subsection{Hazard identification}

Tibbetts (1998) assesses than phycotoxins could be responsible for some 60,000 incidents per year the world over with an overall mortality rate of $1.5 \%$. Incidence and severity are different according to types of toxins. Thus, in view of reported intoxications and deaths, phycotoxins are identified as a matter of concern for human health.

\subsubsection{Okadaic acid and analogs}

Okadaic acid (OA) and its congeners (dinophysistoxins) are produced by two species of dinoflagellates Dynophisis spp and Prorocentrum spp (Hallegraeff, 2003). Historically, OA 
and analogs are classified in Diarrheic Shellfish Poisoning (DSP) because of the symptoms they cause (gastrointestinal distress, diarrhea, nausea, vomiting and abdominal pain). Prior to the 1980's DSP incidents affected mainly Europe (first outbreak in 1961 in the Netherlands) and Japan (the second incident is reported in Japan in the late 1970's), whereas currently diarrheic shellfish toxin outbreaks are documented all over the world. Tens of thousands cases of intoxication have been reported (Picot et al., 2011a), all over the world, but because of nonspecific clinical symptoms, DSP cases are probably underdiagnosed and underreported (Economou et al., 2007). No death has been attributed to OAs.

\subsubsection{Spirolides}

Spirolides (SPXs) are cyclic imines produced by the dinoflagellate Alexandrium ostenfeldii. SPXs are included in the "emerging toxin" group because they have been recently isolated and characterised: in early 1990s, (in scallops and mussels harvested in Nova Scotia, Canada) (Hu et al., 1995). In Europe SPXs have only recently been found in their producer dinoflagellate and/or shellfish in Scotland, Italy, Denmark, Ireland, Norway, Spain and France (in the 2000s). Nowadays, no report of human illness due to SPXs, have been identified. Episodes of toxicity, involving non-specific symptoms such as gastric distress and tachycardia were recorded in individuals in Nova Scotia, (Canada) consuming shellfish during times when SPXs were known to be present, but these could not be definitively ascribed to SPXs and are not consistent with the signs of toxicity in mice (Richard et al., 2001). In mice, acute toxicity of SPXs is characterised by the rapid onset of systemic neurotoxicity following i.p. (intra-peritoneal) injection and death within minutes. Thus SPXs are therefore often denoted "fast acting toxins".

\subsection{Hazard characterization}

As mentioned before, the aim is to allocate two toxicological reference values: the ARfD and the TDI for acute and chronic risks, respectively. The two international organizations which have evaluated toxicological studies and proposed these toxicological reference values are: the JECFA (Joint FAO/WHO (Food and Agriculture Organization / World Health Organization) Expert Committee on Food Additives) ad hoc Expert Consultation on Biotoxins in Bivalve Molluscs and the European Food Safety Authority (EFSA).

\subsubsection{Okadaic acid and analogs}

Human data from Japan (eight people from three families, ages 10-68) indicate a LOAEL (Lowest Observed Adverse Effect Level) of 1.2-1.6 $\mathrm{\mu g} / \mathrm{kg} \mathrm{bw}$. In a second study from Norway, 38 of 70 adults were affected at levels ranging from 1.0 to $1.5 \mu \mathrm{g} / \mathrm{kg}$ bw (Aune and Yndestad, 1993). Based on the LOAEL of $1.0 \mu \mathrm{g}$ OA/ $\mathrm{kg}$ bw and a chosen safety factor of 3 because of documented human cases involving more than 40 people and because DSP symptoms are readily reversible, the JEFCA established a provisional ARfD of $0.33 \mu \mathrm{g}$ OA equ/kg bw. In 2008, the EFSA proposed an ARfD of $0.30 \mu \mathrm{g}$ OA equ/kg bw based on a LOAEL equals to $0.9 \mu \mathrm{g} \mathrm{OA} / \mathrm{kg}$ bw and a chosen safety factor of 3 to the use of a LOAEL instead of a NOAEL (No Observed Adverse Effect Level). The JECFA and the EFSA determined that no TDI could be established because of insufficient data on the chronic effects of OA (EFSA, 2008a; Toyofuku, 2006). 


\subsubsection{Spirolides}

The toxins of the group of SPXs are characterised by binding to and blocking of AChR receptors in the central- and peripheral nervous system including neuromuscular junctions. The acute toxic signs have a rapid onset, in particular following i.p. (intra-peritoneal) administration. With regard to oral toxicity the reported toxicity varies greatly depending on whether the toxin is administered by gavage or in feed and whether the animal is fasted. In general, gavage administration shows lower LD50 (Lethal Dose) values for the various toxins. In humans, no quantitative data on toxicity exist. In view of the acute toxicity of SPXs the EFSA considered that an ARfD should be established for the SPXs, but due to the lack of adequate quantitative data on acute oral toxicity (i.e. no-observed-adverse-effect levels (NOAELs)) this was not possible. However, the toxicology working group of the European Union Community Reference Laboratory for marine biotoxins (CRLMB) had proposed a guidance level of $400 \mu \mathrm{g}$ sum of SPXs/kg shellfish meat (CRLMB, 2005; Pigozzi et al., 2008). But currently there are no regulations on SPXs in shellfish in Europe or in other regions of the world.

There are no long term studies on the group of SPXs in experimental animals. Thus no TDI had been allocated to SPXs.

\subsection{Exposure assessment}

\subsubsection{Input data}

To determine recreational shellfish harvester exposure, shellfish contamination data have to be combined with their shellfish consumption rates. These two kinds of data are lacking. Consumption data often do not distinguish fish and shellfish consumption and do not take into consideration harvested shellfish consumption. Moreover, getting base levels of these phycotoxins $\mathrm{i}$ in the most concerned shellfish i.e. bivalve molluscs, is a prerequisite to any phycotoxin-exposure assessment. Such data are missing because shellfish contamination is only analysed in case of phytoplankton bloom. These considerations led us to monthly monitor these phycotoxins in such species and to conduct a one-year survey of shellfish consumption by recreational shellfish harvesters from the same area (i.e. contamination- and consumption-data collected in the same area and relative to the same subpopulation).

\subsubsection{Shellfish consumption data}

The population of interest was a group of recreational shellfish harvesters set along the coasts of Finistère (Western Brittany, France, see figure 1).

Their shellfish consumption was investigated from February 2008 to February 2009 through two complementary methods: a Food Frequency Questionnaire (FFQ) and a food diary. The FFQ was conducted through face-to-face interviews at the harvesting sites. As this tool provides long-term consumption data, but relies upon memory, this drawback was counteracted by using the records versus time of each shellfish meal (with quantities) kept in the food diary. Moreover, this diary gave additional information such as the origin of consumed shellfish (harvest, shop, restaurant...), consumption by different household members and the way shellfish had been prepared. Data were validated for bivalve and gastropod groups (for more details, see Picot et al., 2011b). The consumption data about five 
of the most consumed bivalve species in the area of interest are expressed as follows in Table 1: portion sizes and daily shellfish consumption rates (both with the mean and 95th percentile (P95)) as well as the raw consumption in percentage.

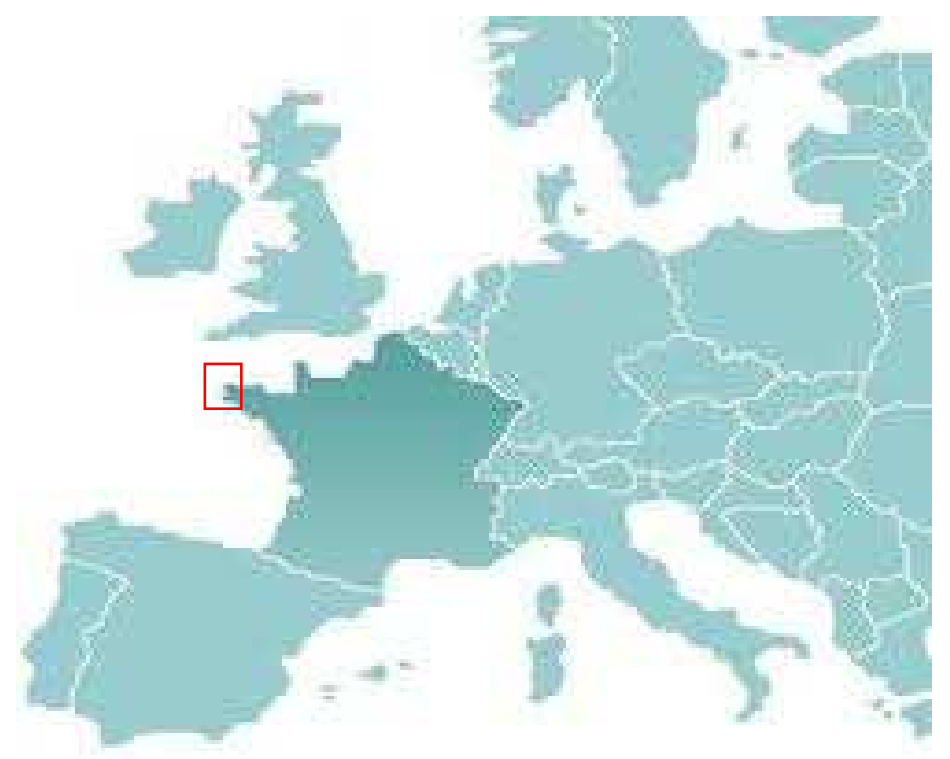

Fig. 1. Description of the area of interest: Finistère, Western Brittany, France.

\begin{tabular}{|c|c|c|c|c|c|c|c|c|c|c|c|}
\hline \multirow{3}{*}{ Bivalve species } & \multicolumn{5}{|c|}{ Consumption derived only from harvested bivalve } & \multicolumn{5}{|c|}{ Consumption derived only from purchased bivalve } & \multirow{3}{*}{$\begin{array}{l}\% \text { of raw } \\
\text { consumption }\end{array}$} \\
\hline & \multirow{2}{*}{$\begin{array}{c}\% \text { of } \\
\text { consumers }\end{array}$} & \multicolumn{2}{|c|}{$\begin{array}{c}\text { Portion size } \\
\text { (g/portion) }\end{array}$} & \multicolumn{2}{|c|}{$\begin{array}{l}\text { Daily consumption } \\
\text { rate ( } \mathrm{g} / \text { day })\end{array}$} & \multirow{2}{*}{$\begin{array}{c}\% \text { of } \\
\text { consumers }\end{array}$} & \multicolumn{2}{|c|}{$\begin{array}{c}\text { Portion size } \\
\text { (g/portion) }\end{array}$} & \multicolumn{2}{|c|}{$\begin{array}{l}\text { Daily consumption } \\
\text { rate ( } \mathrm{g} / \text { day })\end{array}$} & \\
\hline & & Mean & P95 & Mean & P95 & & Mean & P95 & Mean & P95 & \\
\hline Oyster & 20.3 & 36.6 & 172.8 & 1.68 & 7.58 & 27.2 & 34.4 & 102.4 & 2.02 & 8.12 & 97.8 \\
\hline Mussel & 27.3 & 69.4 & 396.0 & 1.66 & 10.1 & 33.6 & 80.0 & 264.0 & 4.04 & 11.6 & 0.00 \\
\hline Cockle & 63.7 & 109 & 271.5 & 3.15 & 13.8 & 2.6 & 2.7 & nc & 0.09 & 0.26 & 2.38 \\
\hline Carpet shell clam & 74.6 & 73.7 & 259.5 & 2.43 & 10.7 & 4.7 & 3.2 & $\mathrm{nc}$ & 0.14 & 0.47 & 31.7 \\
\hline Razor clam & 23.4 & 27.6 & 167.8 & 0.57 & 3.31 & 0.0 & 0.00 & 0.00 & 0.00 & 0.00 & 0.00 \\
\hline King scallop & 0.39 & 0.13 & $\mathrm{nc}$ & 0.0012 & $\mathrm{nc}$ & 20.3 & 15.2 & 85.5 & 0.45 & 2.50 & 3.69 \\
\hline
\end{tabular}

Table 1. Shellfish consumption data according to shellfish species and origin (harvest or purchase). Consumption rates derived from the total population, including non consumers.

\subsubsection{Shellfish contamination data}

To counteract the lack of databases about phycotoxin base levels in shellfish, samples were harvested monthly, from June 2009 to June 2010, on beaches of Finistère selected from three criteria: i) the presence of several bivalve species, ii) regular shellfish harvesters and iii) regular phycotoxin events. The analyses were made on only two among the five bivalve species, which had been previously identified as being either the most consumed species or the most contaminated from a consumption survey and a test about inter-species variability (Picot et al., submitted). OAs and SPXs were analysed after methanolic extraction from samples, purification by solid phase extraction and quantification by High Performance Liquid Chromatography - tandem mass spectrometry (HPLC-MS/MS) (Picot et al., submitted). The results of contamination are presented in the figures 2 and 3 . 


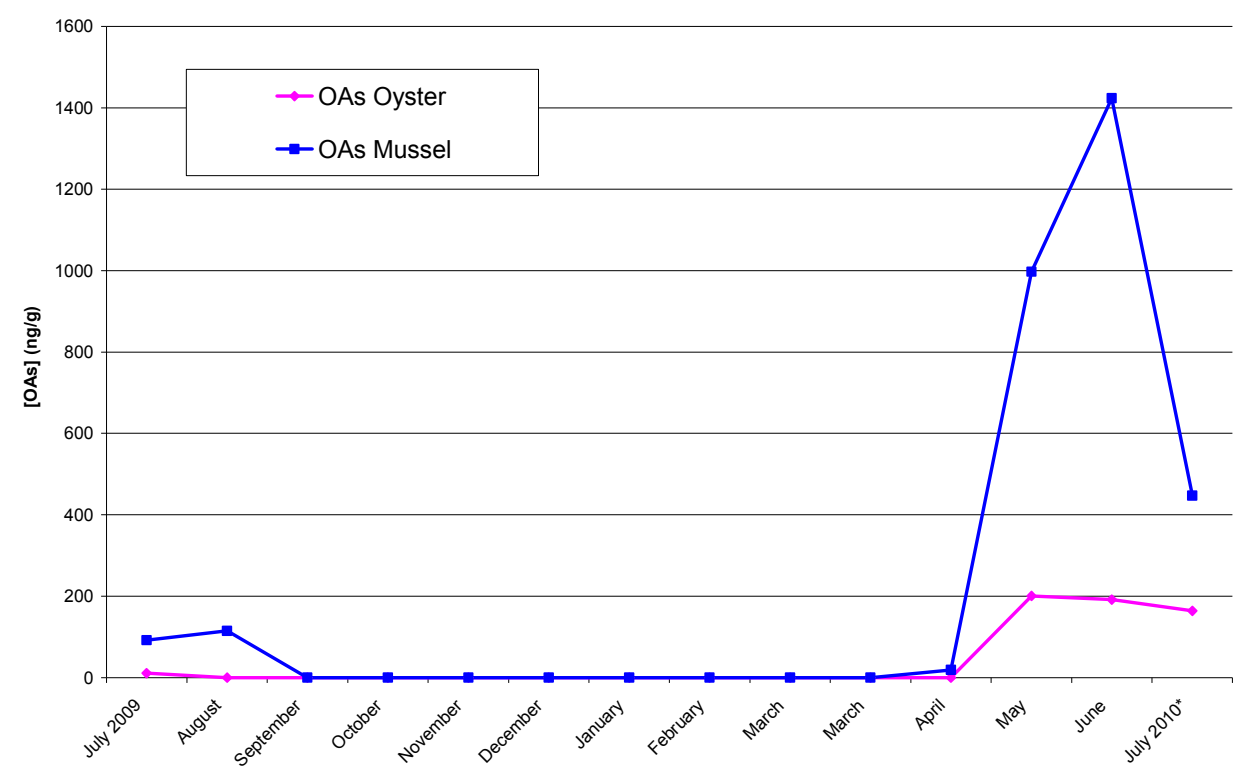

Fig. 2. Okadaic Acid profile of contamination.

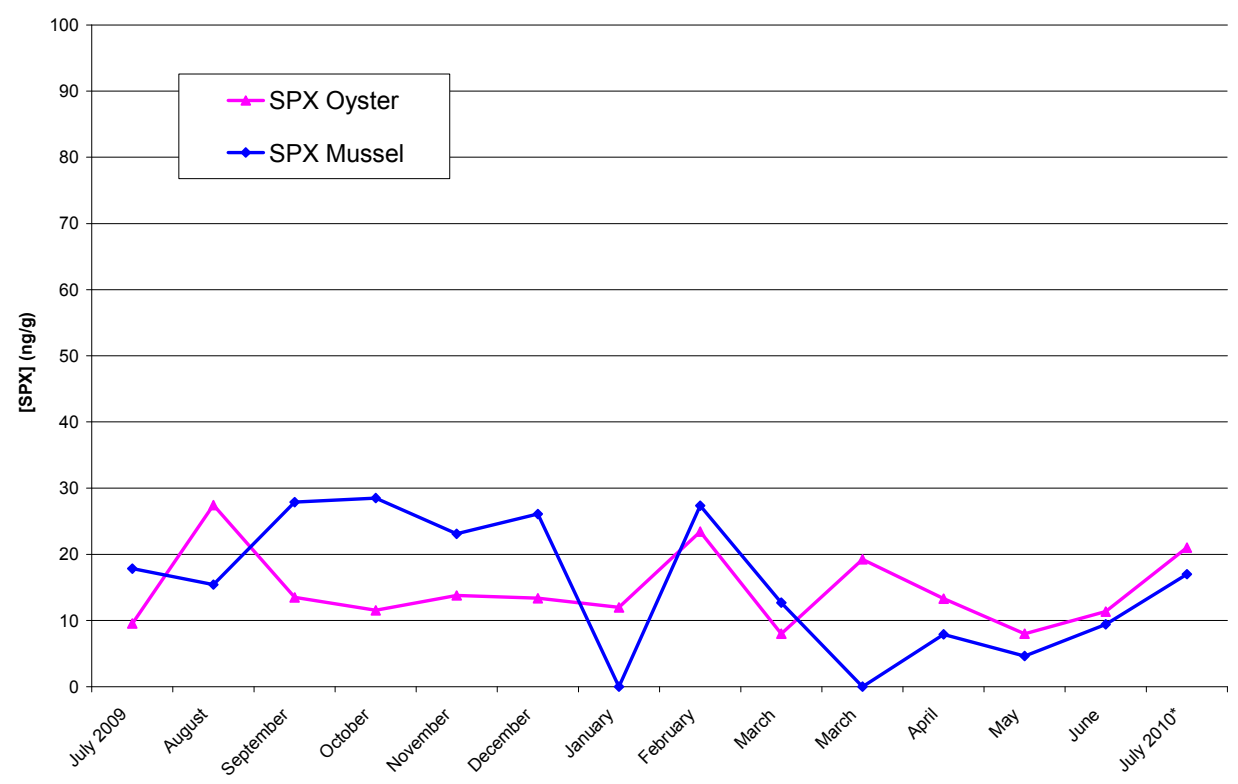

Fig. 3. Spirolides profile of contamination 
Contamination data are often left-censored because of the limits of detection (LOD) and quantification (LOQ) of analytical methods. The GEMS/Food-Euro framework proposed different treatments according to the prevalence of censored-data (WHO, 1995):

- the number of censored data is less than or equal to $60 \%$, then, the censored data are replaced by the corresponding LOD or LOQ divided by 2 (T1);

- the number of censored data is greater than $60 \%$ and then:

- $\quad$ either the censored data are replaced by zero (T2a)

- $\quad$ or they are replaced by the corresponding LOD or LOQ (T2b).

The contamination data are described in Table 2. As, for OAs, the censored data accounted for more $60 \%$ of values, zero and LOD (or LOQ) values were used in two separate estimations of the distributions and calculations (mean, median, percentiles...). On the other hand, as the censored values about SPXs were less than $60 \%$, they were replaced by the half of the corresponding LOD or LOQ.

\begin{tabular}{|c|c|c|c|c|c|c|c|c|c|c|c|c|c|}
\hline \multirow{2}{*}{ Phycotoxin } & \multirow{2}{*}{$\begin{array}{l}\text { Bivalve } \\
\text { species }\end{array}$} & \multirow{2}{*}{$\begin{array}{c}\text { Number of } \\
\text { analyses }(n=)\end{array}$} & \multirow{2}{*}{$\begin{array}{c}<\text { LOD } \\
(\%)\end{array}$} & \multirow{2}{*}{$\begin{array}{c}<\mathrm{LOQ} \\
(\%)\end{array}$} & \multicolumn{3}{|c|}{ Mean } & \multicolumn{3}{|c|}{ Median } & \multicolumn{3}{|c|}{ Max } \\
\hline & & & & & T1 & $\mathrm{T} 2 \mathrm{a}$ & $\mathrm{T} 2 \mathrm{~b}$ & $\mathrm{~T} 1$ & $\mathrm{~T} 2 \mathrm{a}$ & $\mathrm{T} 2 \mathrm{~b}$ & T1 & $\mathrm{T} 2 \mathrm{a}$ & $\mathrm{T} 2 \mathrm{~b}$ \\
\hline OAs & Oysters & 13 & 76.9 & 0 & $\mathrm{nc}$ & 31.0 & 38.7 & $\mathrm{nc}$ & 0.0 & 10.0 & $\mathrm{nc}$ & 200.6 & 200.6 \\
\hline OAs & Mussels & 13 & 61.5 & 0 & $\mathrm{nc}$ & 203.6 & 209.7 & $\mathrm{nc}$ & 0.0 & 10.0 & $\mathrm{nc}$ & 1423 & 1423 \\
\hline SPX & Oysters & 13 & 0 & 0 & 14.2 & $\mathrm{nc}$ & $\mathrm{nc}$ & & $\mathrm{nc}$ & $\mathrm{nc}$ & & nc & $\mathrm{nc}$ \\
\hline SPX & Mussels & 13 & 15.4 & 0 & 15.5 & $\mathrm{nc}$ & $\mathrm{nc}$ & & $\mathrm{nc}$ & nc & & $\mathrm{nc}$ & nc \\
\hline
\end{tabular}

Table 2. Okadaic acid and spirolide contamination data set by shellfish species (ng/g) according to the censored data treatment.

\subsubsection{Exposure modelling}

\subsubsection{General mode exposure}

An acute exposure corresponds to a short exposure to a harmful compound at high dose. Let us consider a phycotoxin denoted by $\mathrm{m}$. The acute phycotoxin exposure is the amount of $\mathrm{m}$ ingested in a single meal. It is obtained by multiplying the edible portion size of one shellfish species by the concentration of $\mathrm{m}$ in this portion. For each phycotoxin, acute intakes were calculated individually for each shellfish species.

Chronic exposure is a repeated exposure to low, or very low, doses for a long time. The chronic phycotoxin exposure is the amount of $\mathrm{m}$ ingested daily from the daily consumption of all shellfish species. The general exposure model used, here, to assess individual phycotoxin intake from shellfish consumption can be expressed as follows:

$$
E_{m}=\frac{\sum\left(C_{m j} * C R_{j} * P_{j}\right)}{B W}
$$

where Em is the individual exposure ( $\mathrm{mg} / \mathrm{kg} \mathrm{bw} /$ day) to the phycotoxin, $\mathrm{m}$, from the ingested shellfish species, $\mathrm{j}, \mathrm{Cmj}$ is the concentration $(\mathrm{mg} / \mathrm{kg}$ ) of the same phycotoxin in the edible portion of the same species, $\mathrm{CRj}$ is the daily consumption rate ( $\mathrm{kg} /$ day) of this species, $\mathrm{Pj}$ is the proportion of a given shellfish species in a consumer diet (unitless), and BW is the consumer body weight $(\mathrm{kg})$ assumed, in this study, to be $60 \mathrm{~kg}$ (USEPA, 2000). 
The difference in acute- and chronic-exposure assessments stands in the consumption parameter to be used: the former takes into account the portion size of a given shellfish species, whereas the latter considers the daily consumption rate of all shellfish species.

In this study, focus was on five of the bivalve species the most consumed in the geographical area under study: oysters, mussels, cockles, carpet shell clams and razor clams.

Moreover, the approach in use for exposure calculation usually depends on the nature of the available data. This study was based on a probabilistic approach described in Kroes et al. (2002) and briefly recalled hereafter.

\subsubsection{Probabilistic approach}

Given that a shellfish consumer will not eat, at each time, the same portion size and that the toxin level in the eaten portion will not be alike, the probabilistic calculation considers all of the combinations of phycotoxin occurrence and consumption data. Distributions for both the food consumption data and the contamination data were used in the model to simulate dietary intakes by repeatedly drawing random values for each input distribution. The description of input variables in terms of distributions allows one to characterise their variability and/or uncertainty. Monte Carlo simulation techniques are used by the model to generate output distributions of dietary intakes liable to be ultimately considered in risk characterization. Output distributions i) give several exposure data (mean, median, minimum, maximum and all percentiles) and ii) include a comprehensive analysis of the sensitivities of the resulting exposure with respect to uncertainties in parameters (Counil et al., 2005; Kroes et al., 2002; Tressou et al., 2004).

\section{- Model assumptions}

The subjective assumptions in use in our simulation model were about factors liable to affect contamination rates such as regulatory limits, inter-species variability and cooking process. Because of their possible impact on the results obtained in exposure assessments, they have to be taken into account to generate the model outputs.

Given that recreational shellfish harvesters can transgress bans, in this study, only the contamination distributions in purchased shellfish were right truncated at the regulatory limits when they exist $(0.16 \mu \mathrm{g} / \mathrm{g}$ for OAs), whereas distributions of harvested shellfish contamination were not truncated (thus contamination higher than regulatory limits can be used).

- Each phycotoxin level is species-specific since the contamination rates are bivalve species-dependent, but the analyses were not made on all species. For each toxin, contamination levels were monthly determined in only two species. For the other ones, a 3-month preliminary study was conducted to gain insight into the variability of inter-species contamination. It allowed us to evaluate, for each toxin, the relationship between the levels of contamination in the most contaminated species and in the other ones, (for more details, see Picot et al., submitted). According to these results, a normal distribution was applied to the contamination levels in the species under study to describe the distributions of the levels in the non-analysed bivalve species. 
- As the phycotoxin levels are affected by the cooking process in use, this parameter has to be considered. The analyses were made on raw bivalves. To take into account the cooking process impact, for each toxin, the ratio between the phycotoxin rates in raw samples and in cooked samples was determined in a preliminary study (for more details, see Picot et al., submitted). Then, a Normal distribution reflecting the difference between the raw and the cooked contamination rates was assigned to the contamination levels of raw bivalves in order to obtain the cooked contamination based on the raw contamination rates.

\section{- Model simulation}

The @Risk package, version 4.5 (Palisade, USA) with the Microsoft Excel spreadsheet under XP (Microsoft, USA) was used to perform risk analysis from Monte Carlo simulations and probability distributions so as to develop the exposure model on taking into account uncertainty and variability. Each simulation was run for 10000 iterations to mimic the inherent uncertainty in shellfish-contamination and -consumption as well as the uncertainty in the mathematical process. The probability of existence of a phycotoxin in shellfish, its level in the shellfish and the probability of human exposure were all outputs of the mathematical model. To help in the identification of critical points in the process, the model sensitivity was analysed.

\subsubsection{Results (output data)}

Acute- and chronic-exposures to each of the phycotoxins under study were assessed through probabilistic approach. With this approach, the exposure assessment model produced, for each phycotoxin, a probability density distribution of dietary intakes from all the bivalves under study.

\subsubsection{Acute exposure}

Acute- exposure corresponds to the phycotoxin intake by an individual over a meal composed of a single portion of bivalves. For each bivalve species, the exposure is, thus, the quantity obtained by multiplying the portion size by the contamination data. Table 3 presents the main results about acute exposure issued from the probabilistic assessment.

\begin{tabular}{|c|c|c|c|c|c|c|}
\hline & \multicolumn{3}{|c|}{$\mathrm{OA}$} & \multicolumn{3}{|c|}{ SPX } \\
\hline & \multicolumn{3}{|c|}{ Exposure $^{*}(\mathrm{ng} / \mathrm{kg}$. bw $/$ portion) } & \multicolumn{3}{|c|}{ Exposure* (ng/kg.bw/portion) $^{*}$} \\
\hline & Mean & Median & P95 & Mean & Median & P95 \\
\hline Harvested oysters & 19.4 & 7.62 & 78.1 & 8.60 & 5.46 & 27.4 \\
\hline Harvested mussels & 456 & 151 & 1912 & 26.0 & 13.3 & 94.8 \\
\hline Harvested cockles & 702 & 243 & 2808 & 78.4 & 49.6 & 250 \\
\hline Harvested carpet shell clams & 378 & 149 & 1466 & 19.8 & 12.3 & 60.00 \\
\hline Harvested razor clams & 133 & 44.9 & 569 & 8.58 & 5.50 & 27.2 \\
\hline Purchased oysters & 17.7 & 7.1 & 72 & 8.10 & 5.21 & 25.5 \\
\hline Purchased mussels & 183 & 79 & 706 & 29.9 & 15.6 & 105 \\
\hline Purchased cockles & 4.00 & 1.7 & 18 & 1.90 & 1.20 & 6.00 \\
\hline Purchased carpet shell clams & 3.80 & 1.5 & 15 & 0.7 & 0.45 & 2.20 \\
\hline Purchased razor clams & 0 & 0 & 0 & 0 & 0 & 0 \\
\hline ARfD & \multicolumn{3}{|c|}{$333^{a} / 300^{b}$} & \multicolumn{3}{|c|}{ No ARfD allocated } \\
\hline
\end{tabular}

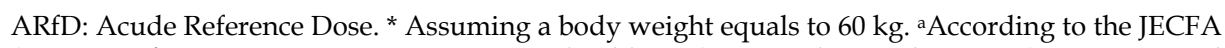

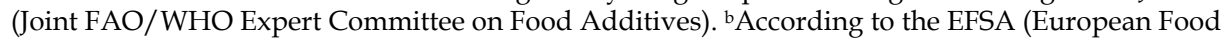
Safety Authority).

Table 3. Acute dietary intakes of okadaic acid and spirolide obtained by a probabilistic approach and comparison with toxicological reference values for each bivalve species. 
- Okadaic acid and analogs

Concerning OAs, the exposure distribution led to a maximal (for harvested cockles) mean value, a median value and a 95th percentile value equal to $0.70,0.24$ and $2.81 \mu \mathrm{g} / \mathrm{kg} \mathrm{bw}$, respectively. Figure 4 shows the acute exposure for each shellfish species.

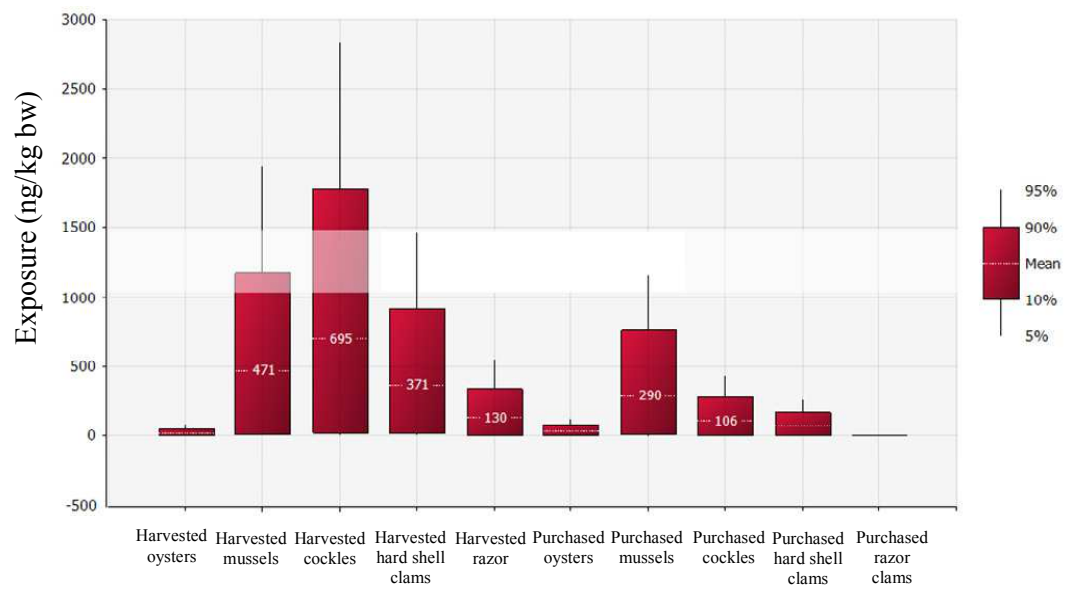

Fig. 4. Acute exposure to Okadaic Acid (ng/kg bw) for each shellfish species.

- Spirolides

For SPXs exposure distribution, the highest (for harvested cockles) mean value, median and 95th percentile were equal to $78.5,49.6$ and $250 \mathrm{ng} / \mathrm{kg} . \mathrm{bw}$, respectively. Figure 5 shows the acute exposure for each shellfish species.

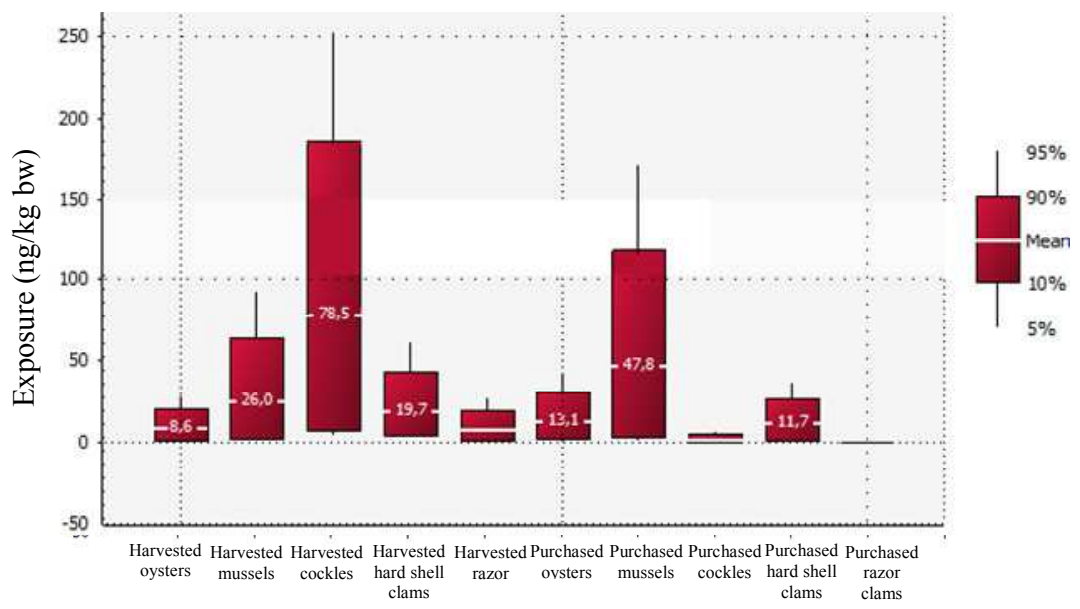

Fig. 5. Acute exposure to Spirolide (ng/kg bw) for each species. 


\subsubsection{Chronic exposure}

The chronic exposure assessment corresponds to the level of exposure after a daily consumption of shellfish, thus the useful consumption data are the daily consumption rates. Table 4 illustrates the chronic-exposure levels issued from the probabilistic exposure approach for harvested-, purchased-bivalves and "all bivalves".

\begin{tabular}{|c|c|c|c|c|c|c|c|}
\hline \multirow{3}{*}{$\begin{array}{l}\text { Censored } \\
\text { values } \\
\text { treatment }\end{array}$} & \multirow{3}{*}{ Bivalve sources } & \multicolumn{3}{|c|}{ OA } & \multicolumn{3}{|c|}{ SPX } \\
\hline & & \multicolumn{3}{|c|}{ Exposure* (ng/kg.bw/day) $^{*}$} & \multicolumn{3}{|c|}{ Exposure $^{*}(\mathrm{ng} / \mathrm{kg} . \mathrm{bw} /$ day $)$} \\
\hline & & Mean & Median & P95 & Mean & Median & P95 \\
\hline$\overline{T 1}(\mathrm{SPX})$ or & Harvested bivalves & 44.4 & 29.3 & 134 & 3.5 & 2.8 & 8.3 \\
\hline T2a (DA & Purchased bivalves & 9.70 & 5.10 & 34.5 & 1.9 & 1.3 & 5.70 \\
\hline and $O A$ ) & All bivalves & 54.1 & 39.0 & 149 & 5.4 & 4.60 & 11.9 \\
\hline \multirow{3}{*}{$\mathrm{T} 2 \mathrm{~b}$} & Harvested bivalves & 45.9 & 30.9 & 137 & & & \\
\hline & Purchased bivalves & 10.3 & 5.40 & 36.6 & & & \\
\hline & All bivalves & 56.2 & 41.1 & 155 & & & \\
\hline \multicolumn{2}{|c|}{ Tolerable Daily Intake } & \multicolumn{6}{|c|}{ No Tolerable Daily Intake allocated } \\
\hline \multicolumn{2}{|c|}{ ARfD } & \multicolumn{3}{|c|}{$333^{\mathrm{a}} / 300^{\mathrm{b}}$} & \multicolumn{3}{|c|}{ No ARfD allocated } \\
\hline
\end{tabular}

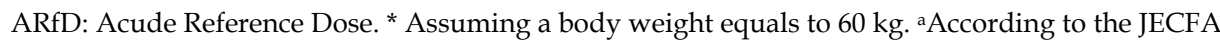
(Joint FAO/WHO Expert Committee on Food Additives). ${ }^{\mathrm{b} A c c o r d i n g}$ to the EFSA (European Food Safety Authority).

Table 4. Chronic dietary intakes of okadaic acid and spirolide obtained by a probabilistic approach for harvested, purchased and all bivalves; and comparison with toxicological reference values.

\section{- Okadaic acid and analogs}

Concerning OAs, the "all bivalves"-related exposure distribution presents maximal means of 54.1 and $56.2 \mathrm{ng} / \mathrm{kg}$ bw/day for T2a and T2b scenarios, respectively, as well as median values of 39.0 and $41.1 \mathrm{ng} / \mathrm{kg}$ bw/day and 95th percentiles of 149 and $155 \mathrm{ng} / \mathrm{kg} \mathrm{bw} /$ day. One should note that the censored value scenario (T2a or T2b) has a very limited effect upon the chronic dietary exposure to phycotoxins. About the comparison of the contribution by harvested bivalves against the one by purchased bivalves, table 4 shows clearly that, for OAs, the intakes derived from harvest are about 5-fold those derived from purchase, mainly because the contamination distribution of harvested bivalves took into account levels above the regulatory limit. The figure 6 shows the exposure distribution of OAs for all species.

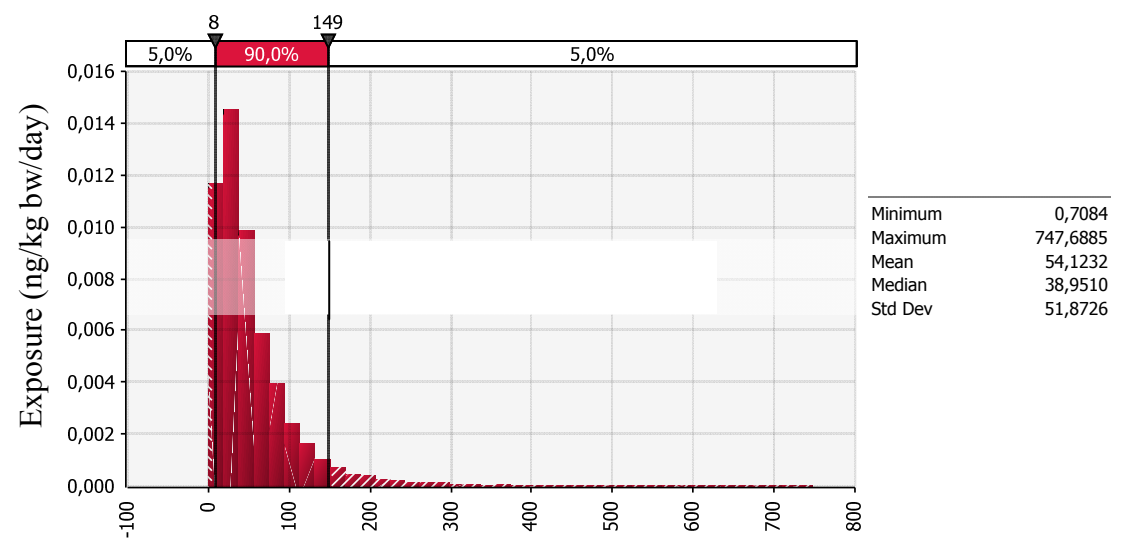

Fig. 6. Chronic exposure distribution to Okadaic Acid (ng/kg bw/day) for all species. 
- $\quad$ Spirolides

Concerning SPX, the chronic distribution of exposure (for "all bivalves") leads to a mean value of $5.4 \mathrm{ng} / \mathrm{kg} \mathrm{bw} /$ day, a median of $4.6 \mathrm{ng} / \mathrm{kg} \mathrm{bw} /$ day, and a 95th percentile of 11.9 ng/kg bw/day.. For SPX, the intakes derived from harvest are about 2-fold those derived from purchase. The figure 7 shows the exposure distribution of OAs for all species.

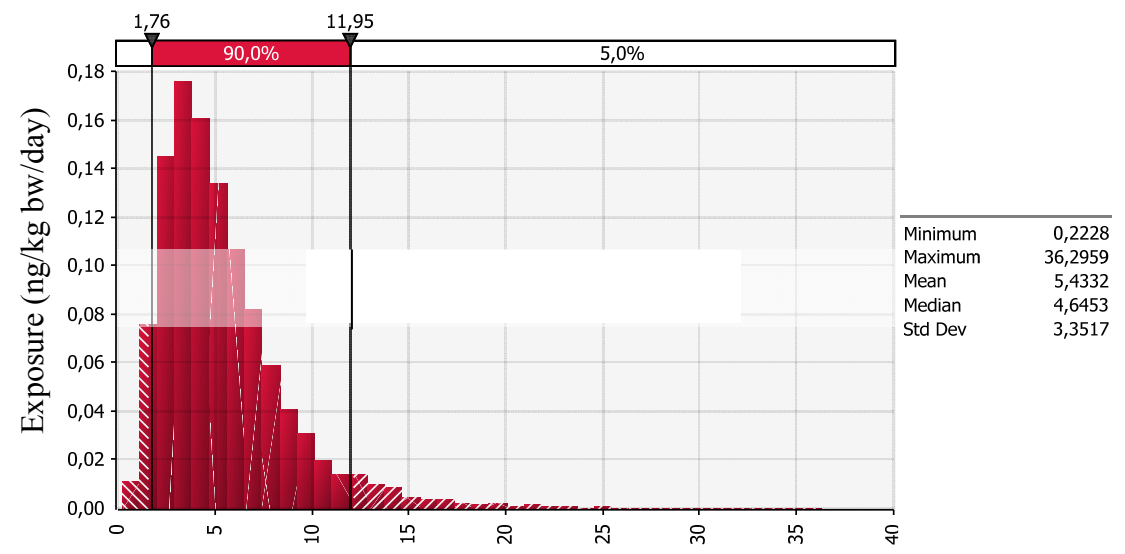

Fig. 7. Chronic exposure distribution to Spirolide (ng/kg bw/day) for all species.

- $\quad$ Species contribution

Figure 8 illustrates the contribution of each bivalve shellfish to the daily intakes of each of the phycotoxin under study. It evidences that the three greatest contributor species are the cockles and the carpet shell clams from harvest as well as the mussels from both harvest and purchase. Their high contributions come from the high consumption and contamination rates for harvested-species and to the high consumption rate for purchased mussels.

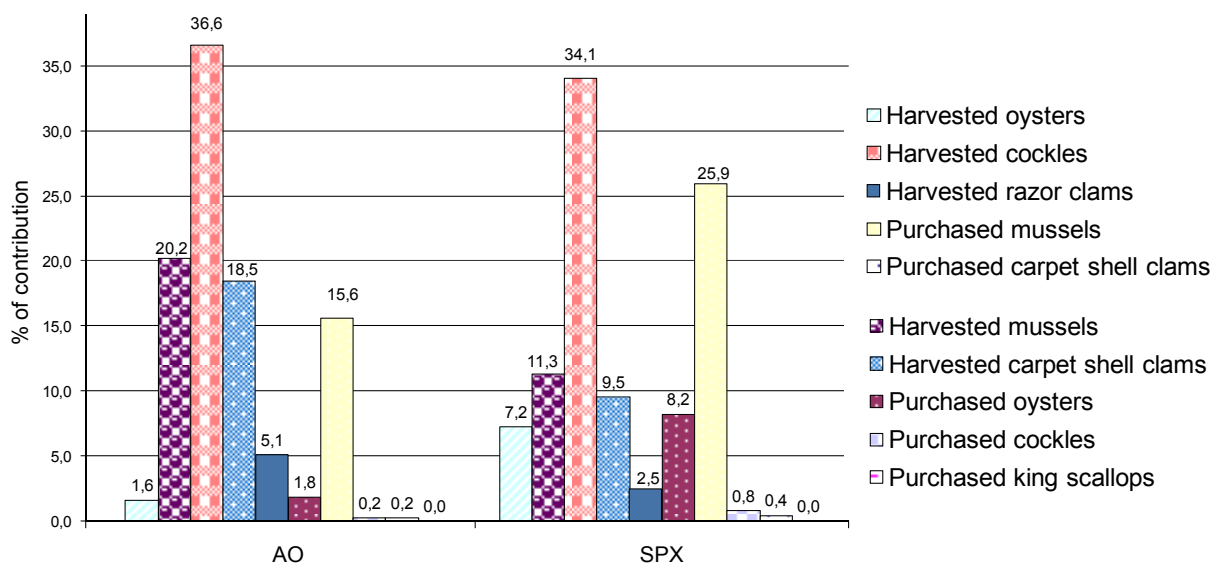

Fig. 8. Contribution of each bivalve species to the daily intakes of okadaic acid and spirolide determined through the probabilistic approach (T2a and T1 treatments of censored values). 


\subsection{Risk characterization}

\subsubsection{Acute risk characterization}

For acute-risk characterization, probabilistic estimates of dietary exposure to phycotoxins have to be compared to the ARfD (Acute Reference Dose). For OAs, the provisional ARfDs established are 0.33 and $0.30 \mu \mathrm{g} / \mathrm{kg}$ bw by the JECFA and the EFSA, respectively, whereas no ARfD has been allocated for SPX (Toyofuku, 2006).

\subsubsection{Okadaic acid and analogs}

Concerning OAs, the highest probabilistic assessment (for harvested cockles) led to a mean exposure and a 95th percentile of, respectively, about 2.5-fold and 9-fold the OA ARfD, but to a median exposure almost 1.25-fold less than the OA ARfD. One should note that, for purchased bivalves, all exposures (means, medians and 95th percentiles) were below than the OA ARfD, excepted for high consumers of mussels, they are above the acute reference value.

\subsubsection{Spirolides}

Characterizing the SPX acute risk by comparison of the acute exposure with the ARfD cannot be realized because of the unavailability of SPX ARfD value explained by the lack of quantitative data on acute oral toxicity by this phycotoxin. However, only in order to have an idea of the order of magnitude of the margin of exposure, the acute exposure could be compared with the $\mathrm{LD}_{0}$ (Lethal Dose) ${ }^{1}$. Munday (2008) studied acute oral exposure to SPX by mice. In the case of oral administration of SPX to mice, it results in two $\mathrm{LD}_{0}$ equal to 53 and $400 \mu \mathrm{g} / \mathrm{kg} \mathrm{bw}$, for gavage and feeding with cheese cream containing SPX, respectively.

In the case of the most representative way of administration (mice feeding with cheese cream containing SPX), the highest probabilistic assessment (for harvested cockles) led to a mean exposure and a 95th percentile of, respectively, about 5000-fold and 1600-fold less than the SPX $\mathrm{LD}_{0}$. Comparing with the most protective $\mathrm{LD}_{0}(=53 \mu \mathrm{g} / \mathrm{kg} \cdot \mathrm{bw})$, the highest probabilistic assessment (for harvested cockles) led to a mean exposure and a 95th percentile of, respectively, about 675-fold and 210-fold less than the SPX $\mathrm{LD}_{0}$.

Since the margin of exposure is higher than 100, it seems appear that acute SPX is not a matter of concern for human health. But this conclusion has to be confirmed with other relevant toxicological studies, allowing to establish an ARfD for SPX.

\subsubsection{Chronic risk characterization}

For chronic risk characterization, probabilistic estimates of dietary exposure to phycotoxins have to be compared to the TDI. But, as no TDI has been allocated to phycotoxins by international committees, we used two other methods, not satisfactory but the only ones possible: comparison with the corresponding ARfD and with the Threshold of Toxicological Concern (TTC). The TTC is a principle, which refers to the establishment of a human exposure threshold value for all chemicals, below which there would be no appreciable risk

\footnotetext{
${ }^{1} \mathrm{LD}_{0}$ (Lethal Dose 0): the amount of a chemical that if administered to an animal will kill $0 \%$ of the sample population.
} 
to human health. This threshold value is equal to $2.5 \mathrm{ng} / \mathrm{kg} \mathrm{bw} /$ day for genotoxic substances and $25 \mathrm{ng} / \mathrm{kg}$ bw/day for all other substances (Kroes et al., 2004; EFSA, 2011).

\subsubsection{Okadaic acid and analogs}

- Comparison with TTC

Concerning OAs, the levels of exposure are equal to 54; 39 and $149 \mathrm{ng} / \mathrm{kg}$ bw/day, for the mean, median and 95th percentile, respectively. These levels of exposure are not below the TTC, thus it cannot be excluded that there would be a risk to human health.

- Comparison with ARfD

For OAs, the values of the mean and 95th percentile intake issued from the probabilistic approach $(0.054$ and $0.15 \mu \mathrm{g} / \mathrm{kg}$ bw/day, respectively) are only about 5- and 2-fold less than the most protective OA ARfD $(0.30 \mu \mathrm{g} / \mathrm{kg} \mathrm{bw})$. Thus chronic OA intakes were close to ARfD. TDI is, by definition, less than ARfD. The former is, indeed, derived from a NOAEL value or a LOAEL one determined from long-term toxicological studies, whereas the latter is determined from acute toxicological studies. Moreover, in addition to the traditional security factors employed for ARfD, the establishment of TDI requires the use of a few other ones such as, for example, an uncertainty factor of 10 to extrapolate subchronic to chronic exposure (Lewis, 1995), leading to TDIs much lower than ARfD. The finding, in this study, of a chronic exposure to OA via shellfish consumption (only 2 to 5fold below the ARfD) suggests that OA should be considered as a possible cause for concern about human health.

\subsubsection{Spirolides}

\section{- Comparison with TTC}

For SPX, the values of the mean, the median and 95th percentile intake issued from the probabilistic approach (5.4; 4.6 and $11.9 \mathrm{ng} / \mathrm{kg}$ bw/day, respectively) are higher than the TTC ( $2.5 \mathrm{ng} / \mathrm{kg}$ bw/day). We made the comparison with the most protective TTC because no (sub)chronic and genotoxic data are available for SPX. Thus, the only exposure data do not allow to reject a chronic risk due to SPX.

\section{- Comparison with ARfD}

As neither ARfD nor TDI have been allocated to SPX by international committees, no comparison can be made. Though there is no toxicological reference value, the calculations made in this study highlighted the regular exposure of humans to low SPX doses. Thus, in the case where toxicological data indicate chronic impact by SPX on health, it would be worth taking into account exposure to SPX.

\section{Conclusion}

Further to the increasing number of reports about phycotoxin-induced intoxications and deaths, these compounds have become a matter of concern for human health. But, phycotoxin exposure assessments are almost non-existent because related data about consumption and contamination are missing. This led us to study, in the same geographical area, shellfish consumption by humans and shellfish contamination by 
phycotoxins to assess exposure of humans to these compounds. The acute- and chronicexposure assessments made a probabilistic approach showed that: i) in terms of acute risk, OAs appear to be a cause for concern about high consumers in cases of high contamination levels that may exceed the OA ARfD. For instance, a high and bantransgressing consumer could be exposed to an OA acute intake up to 9-fold the ARfD; ii) about chronic risk, the finding of daily OA intakes close to the ARfD, known to be, by definition, much greater than the TDI, suggests that, among the phycotoxins under study, $\mathrm{OA}$ is the one to be considered. Moreover, it should be noted that bivalves contain regularly SPX at low concentrations. Chronic and subchronic data on SPX are missing, but in case of (sub)chronic toxicity, SPX exposure should be taken into consideration.

These phycotoxin-exposure assessments were aimed at making a first realistic evaluation of human exposure to phycotoxins. Their interest stands in the facts that: i) they were based on consumption- and contamination-data in the same subpopulation and area, ii) the recreational shellfish harvesters under study constitute an at-risk subpopulation iii) interspecies variability in contamination and consumption data was taken into account, iv) the impact of cooking process on phycotoxin levels was also considered.

To gain more comprehensive insight into this health issue, in the future, it would be worth: i) increasing the number of shellfish species to be investigated, ii) considering the contamination data relative to recorded cases of intoxication further to ingestion of fish and crustaceans, iii) extending the contamination database to several years and iv) studying coexposure to several phycotoxins.

\section{References}

Ade P., Funari E., Poletti R. (2003). Risk to human health associated with marine toxic algae. Ann Ist Super Sanita, 39, 53-68.

Aune, T., Yndestad, M. (1993). Diarrhetic shellfish poisoning. Dans : Falconer IR (éditions), Algal Toxins in Seafood and Drinking Water, Academic Press, San Diego, California, USA., 87-104 p.

Burger J., Sanchez J., Gochfeld M. (1998). Fishing, consumption, and risk perception in fisherfolk along an east coast estuary. Environmental Research, 77, 25-35.

CAC (Codex Alimentarius Commission). (2006). Codex Alimentarius Commission Procedural Manual. 16th edition. Joint FAO/WHO Food Standards Programme. Available at: ftp://ftp.fao.org/codex/Publications/ProcManuals/Manual 16e.pdf (accessed April 4, 2010).

Counil, E., Verger, P., Volatier, J.L. (2005). Handling of contamination variability in exposure assessment: A case study with ochratoxin A. Food and Chemical Toxicology, 43, 1541-1555.

CRLMB (Community Reference Laboratory for Marine Biotoxins). (2005). Report on toxicology working group meeting, Cesenatico, Italy, 24-25 October, 2005. Available from http://www.aesan.msps.es/en/CRLMB/web/home.shtml.

Economou, V., Papadopoulou, C., Brett, M., Kansouzidou, A., Charalabopoulos, K., Filioussis, G., et al. (2007). Diarrheic shellfish poisoning due to toxic mussel 
consumption: the first recorded outbreak in Greece. Food Additives and Contaminants, 24, 297-305.

EFSA (European Food Safety Agency). (2008a). Opinion of the Scientific Panel on Contaminants in the Food chain on a request from the European Commission on marine biotoxins in shellfish - okadaic acid and analogues. The EFSA Journal, 589, $1-62$.

EFSA (European Food Safety Authority). (2008b.) Guidance Document for the Use of the Concise European Food Consumption Database in Exposure Assessment (adopted on 17 March 2008). EFSA/DATEX/2008/01, Parma, Italy.

EFSA (European Food Safety Agency). (2010). EFSA Panel on Contaminants in the Food Chain (CONTAM); Scientific Opinion on marine biotoxins in shellfish - Cyclic imines (spirolides, gymnodimines, pinnatoxins and pteriatoxins). The EFSA Journal, 1628, 1-39.

EFSA (European Food Safety Agency). (2011). EFSA Scientific Committee; Draft Scientific Opinion on Exploring options for providing preliminary advice about possible human health risks based on the concept of Threshold of Toxicological Concern (TTC). Available online: www.efsa.europa.eu

Frémy, D.J., Lassus, P. (2001). Toxines d'algues dans l'alimentation. Editions Quae, France, $558 \mathrm{p}$.

Gagnon F., Tremblay T., Rouette J., Cartier J. (2004). Chemical risks associated with consumption of shellfish harvested on the north shore of the St. Lawrence River's lower estuary. Environ Health Perspectives, 112, 883-888.

Hallegraeff, G.M. (2003). Harmful algal blooms: A global overview. In : Hallegraeff, G.M., Anderson, D.M., Cembella, A.D., (éditions), Manual on Harmful Marine Microalgae. Intergovernmental Oceanographic Commission of UNESCO, Paris, France.

Hu, T., Curtis, J.M., Oshima, Y., Quilliam, M.A., Walter, J.A., Watson-Wright, W.M., Wright, J.L.C. (1995). Spirolides B and D, two novel macrocycles isolated from the digestive glands of shellfish. Journal of the chemical society, Chemical communications, 20, 2159-2161.

Kroes R., Müller D., Lambe J., Löwik M.R.H., Van Klaveren J., Kleiner J., et al. (2002). Assessment of intake from the diet. Food Chemical Toxicology, 40, 327-385.

Kroes R., Renwick A.G., Cheeseman M., Kleiner J., Mangelsdorf I., Piersma A., et al. (2004). Structure-based thresholds of toxicological concern (TTC): guidance for application to substances present at low levels in the diet. Food and chemical toxicology, 65-83.

Leblanc JC. (2006). CALIPSO, Fish and seafood consumption study and biomakers of exposure to trace elements, pollutants and Omega-3. AFSSA (French food safety agency), 2006. Available at http://www.afssa.fr/Documents/PASER-RaCalipso.pdf (accessed June 19, 2010).

Lewis S.C. (1995). Subchronic to chronic exposure extrapolation: Toxicologic evidence for a reduced uncertainty factor. Human and Ecological Risk Assessement, 1, 516526. 
Munday R., 2008. Toxicology of cyclic imines: gymnodimine, spirolides, pinnatoxins, pteriatoxins, prorocentrolide, spiro-prorocentrimine, and symbioimines. In: Seafood and Freshwater toxins: Pharmacology, Physiology and Detection. 2nd edition. Ed LM Botana. CRC Press (Taylor and Francys Group), Boca Raton, FL, 581-594.

Picot C., Nguyen T.A., Roudot A.C., Parent-Massin D. (2011a). A Preliminary Risk Assessment of Human Exposure to Phycotoxins in Shellfish : A Review. Human and Ecological Risk Assessement: an international journal, 17, 328-366.

Picot C., Nguyen T.A., Carpentier F.G., Roudot A.C., and Parent-Massin D. (2011b). Relevant shellfish consumption data for dietary exposure assessment among high shellfish consumers, Western Brittany, France. International Journal of Environmental Health Research, 21, 86-105.

Picot C., Limon G., Durand G., Wesolek N., Parent-Massin D., and Roudot A.C. Domoic acid, okadaic acid and spirolides: inter-species variability in contamination and cooking effects. Environ Res, Submitted.

Pigozzi S., Bianchi L., Boschetti L., Cangini M., Ceredi A., Magnani F., et al. (2008). First evidence of spirolide accumulation in northwestern Adriatic shellfish. Copenhagen, 319-322.

Richard, D., Arsenault, E., Cembella, A.D., Quilliam, M.A. (2001). Investigations into the toxicology and pharmacology of spirolides, a novel group of shellfish toxins. Dans : Harmful Algal Blooms 2000, Hallegraef, G.M., Blackburn, S.I., Bolch, C.J., Lewis, R.J (editions), Intergovernmental of Oceanographic Commision of UNESCO, 383-386 p.

Shumway, S.E., Van Egmond, H.P., Hurst, J.W., et al. (1995). Management of shellfish resources. In : Hallegraeff, G.M., Anderson, D.M., et Cembella, A.D. (editions), Manual on Harmful Marine Microalgae. IOC Manuals and Guides no. 33, 433-474 p. Intergovernmental Oceanographic Commission of UNESCO, Paris, France.

Tibbetts J. (1998). Toxic tides. Environmental health perspectives, 106, A326-331.

Toyofuku, H. (2006). Joint FAO/WHO/IOC activities to provide scientific advice on marine biotoxins (research report). Marine pollution bulletin, 52, 1735-1745.

Tressou, J., Crépet, A., Bertail, P., Feinberg, M., Leblanc, J.C. (2004). Probabilistic exposure assessment to food chemicals based on extreme value theory. Application to heavy metals from fish and sea products. Food and Chemical Toxicology, 42, 1349-1358.

USEPA (United States Environmental Protection Agency). (1998). Guidance for Conducting Fish and Wildlife Consumption Surveys. United States Environmental Protection Agency, EPA-823-B-98-007, Office of Water, Washington, $157 \mathrm{p}$.

USEPA (United States Environmental Protection Agency). (2000). Guidance for Assessing Chemical Contaminant Data for Use. Fish Advisories - Fish Sampling and Analysis, Volume 1, Third Edition. United States Environmental Protection Agency, 823-B00-007, Office of Water, Washington, 383 p.

Van Dolah, F.M. (2000). Marine Algal Toxins: Origins, Health Effects, and Their Increased Occurrence. Environmental Health Perspectives, 108, S133-141. 
WHO (World Health Organization). (1985). Guidelines for the study of dietary intakes of chemical contaminants, WHO Offset Publication, n 87, Geneva, Switzerland, $104 \mathrm{p}$.

WHO (World Health Organization). (1995). GEMS/Food-EURO Second Workshop on Reliable Evaluation of Low-Level Contamination of Food, Kulmbach, Germany, EUR/ICP/EHAZ.94.12/WS04-FSR/KULREP95. 


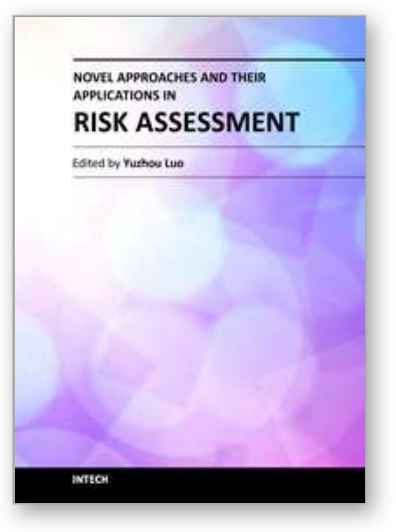

\author{
Novel Approaches and Their Applications in Risk Assessment \\ Edited by Dr. Yuzhou Luo
}

ISBN 978-953-51-0519-0

Hard cover, 344 pages

Publisher InTech

Published online 20, April, 2012

Published in print edition April, 2012

Risk assessment is a critical component in the evaluation and protection of natural or anthropogenic systems. Conventionally, risk assessment is involved with some essential steps such as the identification of problem, risk evaluation, and assessment review. Other novel approaches are also discussed in the book chapters. This book is compiled to communicate the latest information on risk assessment approaches and their effectiveness. Presented materials cover subjects from environmental quality to human health protection.

\title{
How to reference
}

In order to correctly reference this scholarly work, feel free to copy and paste the following:

Cyndie Picot and Alain-Claude Roudot (2012). A Practical Example of Risk Assessment - Risk Assessment to Phycotoxins in a Recreational Shellfish Harvester's Subpopulation, Novel Approaches and Their Applications in Risk Assessment, Dr. Yuzhou Luo (Ed.), ISBN: 978-953-51-0519-0, InTech, Available from:

http://www.intechopen.com/books/novel-approaches-and-their-applications-in-risk-assessment/a-practicalexample-of-risk-assessment-risk-assessment-to-phycotoxins-in-a-recreational-shellfish-ha

\section{INTECH}

open science | open minds

\section{InTech Europe}

University Campus STeP Ri

Slavka Krautzeka 83/A

51000 Rijeka, Croatia

Phone: +385 (51) 770447

Fax: +385 (51) 686166

www.intechopen.com

\section{InTech China}

Unit 405, Office Block, Hotel Equatorial Shanghai

No.65, Yan An Road (West), Shanghai, 200040, China

中国上海市延安西路65号上海国际贵都大饭店办公楼 405 单元

Phone: +86-21-62489820

Fax: $+86-21-62489821$ 
(C) 2012 The Author(s). Licensee IntechOpen. This is an open access article distributed under the terms of the Creative Commons Attribution 3.0 License, which permits unrestricted use, distribution, and reproduction in any medium, provided the original work is properly cited. 